\title{
Early prosthetic and orthopedic assistance in medical rehabilitation of children with congenital and amputation defects of the lower limbs
}

\author{
V.G. Susliaev ${ }^{1,2}$, K.K. Shcherbina ${ }^{1}$, L.M. Smirnova ${ }^{1,3}$, Yu.I. Zamilatsky ${ }^{1}$, A.A. Koltsov ${ }^{1}$, A.V. Sokurov ${ }^{1}$, \\ T.V. Ermolenko ${ }^{1}$ \\ ${ }^{1}$ Federal Scientific Center of Rehabilitation of the Disabled named after G.A. Albrecht, Saint Petersburg, Russian Federation
${ }^{2}$ The main bureau of medical and social expertise in St. Petersburg, Saint Petersburg, Russian Federation \\ ${ }^{3}$ Saint Petersburg State Electrotechnical University LETI, Saint Petersburg, Russian Federation
}

\begin{abstract}
Introduction The quality of medical rehabilitation and habilitation of children with lower limb defects depends on early prosthetic and orthopedic care. Purpose Analysis of the provision of prosthetic and orthopedic care for children with orthopedic pathology of the lower extremities at the Federal Scientific Center of Rehabilitation of the Disabled named after G.A. Albrecht. Methods The results of rehabilitation and habilitation of 261 children with orthopedic pathology of the lower extremities were studied. Methods of clinical examination, radiography, physiological and biomechanical study were applied. Statistical analysis was carried out. Results In 261 cases studied, the causes of defects were congenital anomalies (82 \%) and amputation defects (18\%). Surgical preparation for prosthesis application was performed in 85 cases (33 \%). More than half of the patients who sustained interventions had a defect at the hip level. The anatomical and functional features of stumps in children with abnormal development of the lower extremities were studied and the principles of prosthesis and orthosis application were developed. Discussion Delay in prosthesis application leads to negative effects on the child's body. The supply of children with technical means of rehabilitation is not regulated in due manner by the current legislation, which leads to the complexity of the purpose of the product and the delay in the timing of prosthesis and orthosis fitting. Early prosthetic and orthopedic care for children with orthopedic pathology of the lower limb is a prerequisite for normal development of their growing body. Due to subjectivity of child's assessment of the results of prosthetic fitting, there is high risk of secondary deformities of the child's musculoskeletal system; for children using limb prostheses and orthoses, it is necessary to use an objective instrumental assessment of the results of prosthesis application; dispensary observation; monitoring of motor loads and the technical condition of the prosthesis. Early prosthetic and orthopaedic assistance to children should be conducted not only according to the rules of registration of the individual program for rehabilitation and habilitation (IPRH), but also followed to disability with the aim of preventing the development of complications, injuries, diseases of the musculoskeletal system, and impairment of functional disorders.

Keywords: medical rehabilitation, children, orthesis, prosthesis, lower limb
\end{abstract}

\section{INTRODUCTION}

The Convention on the Rights of the Child proclaims the right of children to healthy growth and development [1]. In this regard, the provision of early prosthetic and orthopedic care for children with orthopedic pathology and identification of their needs for technical means of rehabilitation (TMR) have been recognized as priority tasks. Preparation and prosthetic application are an integral part of medical rehabilitation, and early primary prosthetic management is comparable in its importance to the timely provision of specialized medical care.

For the first time, the principles of early prosthetic and orthopedic assistance to children after amputation or with abnormal limb development were reflected in the scientific works of the specialists of the Federal
State Research Centre named after G.A. Albrecht of the Ministry of Labour of Russia [2]. The relevance of this problem has been confirmed in numerous scientific works [3-10], as well as in the monograph by Rene Baumgartner and Pierre Bott [11]. Currently, the evaluation of the results of rehabilitation treatment and prosthetic management in children with lower limb defects is relevant taking into account the International Classification of Functioning, Disability and Health (ICF) [12]. The aim of the article is the analysis and exchange of experience in the provision of prosthetic and orthopedic care for children with orthopedic pathology of the lower extremities at the FSBI Federal G.A. Albrecht Scientific Centre of the Ministry of Labour of Russia.

\section{MATERIAL AND METHODS}

The results of medical rehabilitation and habilitation in 261 children of both sexes aged from one to 18 years with orthopedic pathology of the lower extremities, who had inpatient and outpatient treatment and prosthetic management at the clinic of the Federal Centre in 20162018, were analysed.

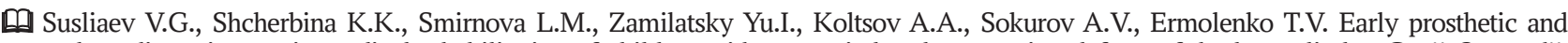
orthopedic assistance in medical rehabilitation of children with congenital and amputation defects of the lower limbs. Genij Ortopedii, 2020, vol. 26, no 2, pp. 198-205. DOI 10.18019/1028-4427-2020-26-2-198-205 
Patient's hospital records and protocols of biomechanical studies were studied. The general condition of patients, the level of their psychomotor development, dynamics and the result of mastering the use of prosthetic and orthopedic products were evaluated.

To assess the condition of the patient's musculoskeletal system and the results of prosthetic management, methods of clinical examination, radiography, physiological and biomechanical study (baroplantography, balansography in the supporting contour of the feet, podography) were used. For this purpose, the systems with matrix pressure meters in the insoles of DiaSled and F-Scan film sensors, and a high-speed digital thermal imager TVS300-honey were utilized.

The results were studied with the Excel parametric and nonparametric statistical analysis.

\section{RESULTS}

In the period 2016-2018, 261 children with defects of the lower extremities were examined at the clinic of the Federal G.A. Albrecht Scientific Centre (Table 1). Analysis of their medical records showed that the main causes of defects were congenital malformations of the extremities in 215 patients $(82.4 \%)$. The causes of amputation defects were the consequences of injuries (three patients), vascular and infectious lesions (caused by meningococcal infection) (eight patients). In one child, the cause of amputation was malignant neoplasms of the bones and soft tissues of the limb.

Surgical preparation for prosthetic fitting over a three-year period was performed in 85 children. The need for surgical treatment prevailed in patients with defects at the femur level - $50.6 \%$ (Table 2).

The following defects and diseases of the stump were noted in children in need of prosthetic fitting: a mal-shaped stump (less often, club-shaped; more often, conical, reducing limb support ability); joint contractures; varus fibula; sawn bone end under the skin; painful adhered scars; ankylosis of the overlying joint. In some patients, a combination of two to three malformations of the stump was observed at the same time (presence of flexion contracture of the knee joint with extensive scars of the skin and protrusion of the sawn bone end). The anatomical and functional state of the stump was significantly different in children when compared with adult patients.

According to our observation, the characteristic anatomical and functional features of the stump formed after lower limb amputation in children are presented in Table 3. The term "rare" in this table refers to the observation of only solitary cases (not more than $5 \%$ ), and "frequent" (more than $75 \%$ ).

Table 1

Characteristics of the examined of children with the lower extremities defects in the period 2016-2018

\begin{tabular}{|c|c|c|c|c|c|}
\hline \multirow{3}{*}{\multicolumn{2}{|c|}{ Lower limb defect }} & \multicolumn{3}{|c|}{ Years } & \multirow{2}{*}{ TOTAL } \\
\hline & & \multirow{3}{*}{$\begin{array}{c}2016 \\
\text { Number (\%) } \\
5(6.3)\end{array}$} & \multirow{3}{*}{$\begin{array}{c}2017 \\
\text { Number (\%) } \\
11(10.9)\end{array}$} & \multirow{3}{*}{$\begin{array}{c}2018 \\
\text { Number (\%) } \\
7(8.6)\end{array}$} & \\
\hline & & & & & Number (\%) \\
\hline \multirow{3}{*}{$\begin{array}{l}\text { Amputation } \\
\text { defect }\end{array}$} & congenital & & & & $23(8.8)$ \\
\hline & acquired & $9(11.4)$ & $6(5.9)$ & $8(9.9)$ & $23(8.8)$ \\
\hline & total & $14(17.7)$ & $17(16.8)$ & $15(18.5)$ & $46(17.6)$ \\
\hline \multicolumn{2}{|c|}{ Congenital malformation, total } & $65(82.3)$ & $84(83.2)$ & $66(81.5)$ & $215(82.4)$ \\
\hline & Total & $79(100)$ & $101(100)$ & $81(100)$ & $261(100)$ \\
\hline
\end{tabular}

Table 2

Information on surgical interventions based on the level of the lower limb defect in the period 2016-2018

\begin{tabular}{|l|c|c|c|c|}
\hline \multirow{2}{*}{ Defect level } & \multicolumn{3}{|c|}{ Years } & \multirow{2}{*}{ TOTAL } \\
\cline { 2 - 5 } & 2016 & 2017 & 2018 & Number (\%) \\
\cline { 2 - 5 } & Number (\%) & Number (\%) & Number (\%) & $6(7.0)$ \\
\hline Hip disarticulation & $3(9.7)$ & $3(10.3)$ & $0(0)$ & $43(50.6)$ \\
\hline Femur & $17(54.8)$ & $14(48.3)$ & $12(48.0)$ & $31(36.5)$ \\
\hline Tibia & $9(29.0)$ & $10(34.5)$ & $12(48.0)$ & $5(5.9)$ \\
\hline Foot & $2(6.5)$ & $2(6.9)$ & $25(100)$ & $85(100)$ \\
\hline Total of patients & $31(100)$ & $29(100)$ & & \\
\hline
\end{tabular}


Anatomical and functional features of lower limb stumps after amputation in children and adults

\begin{tabular}{|c|c|c|}
\hline Anatomical and functional features & Children & Adults \\
\hline Stump shape & $\begin{array}{l}\text { Conical or sharply conical that forms during } \\
\text { physiological growth }\end{array}$ & $\begin{array}{l}\text { Cylindrical or mild cylindrical, } \\
\text { rarely conical }\end{array}$ \\
\hline Stump end supportability & $\begin{array}{l}\text { Sharply decreases if amputation is at the level of } \\
\text { diaphysis }\end{array}$ & No change \\
\hline $\begin{array}{l}\text { Ability to deformities of joint, } \\
\text { bone and reduction axis }\end{array}$ & $\begin{array}{l}\text { Frequent (valgus, varus, anteflexion, } \\
\text { retroflexion) }\end{array}$ & Rare \\
\hline Shortening of the truncated limb & Progresses & Absent \\
\hline Condition of the above lying joints & $\begin{array}{l}\text { Non-proportional growth of joints and bones of } \\
\text { the truncated limb as compared with an intact one }\end{array}$ & Frequent deforming arthrosis \\
\hline - joint contracture & Rare & Frequent \\
\hline - joint recurvatum & Frequent & Rare \\
\hline Stump soft-tissue atrophy & Frequent & Frequent \\
\hline Stump bone tissue atrophy & Frequent (thinning of the cortical layer) & $\begin{array}{l}\text { Frequent (frequent } \\
\text { osteoporosis with thickening } \\
\text { of the cortical layer) }\end{array}$ \\
\hline Neck-to-shaft angle & Tends to increase & Practically no change \\
\hline Osteophytes & Rare & Frequent \\
\hline Phantom pain & None or rare & Frequent \\
\hline Painful neuromas & Rare & Frequent \\
\hline Penetration of stump soft tissues & Frequent during stump growth & Rare \\
\hline
\end{tabular}

Courses of physiotherapy, therapeutic physical exercises and massage helped to improve joint mobility in the presence of contractures and the condition of scarchanged stump tissues, to relieve pain and inflammatory processes. To stimulate tissue regeneration and shorten the recovery period, physiotherapeutic treatment was also performed after the surgical treatment. Adaptive physical education and sports practicing on prostheses are of great importance.

Defects and diseases of the stump that impede functional prosthetic fitting were an indication for surgical treatment and careful choice of the design of prosthetic and orthopedic products, selection of the shape of the socket, laying of its walls according to the shape of the stump or with a special insert sleeve.

Table 4 summarizes the solutions used by the Centre's specialists to solve the problems that arise when choosing the design of an orthopedic product for a child.

The most important task is to correct the limb length for prosthetic management in children with congenital lower limb shortening to prevent secondary deformities and diseases of the musculoskeletal system. Orthopedic shoes, tutors, devices or prostheses for an underdeveloped limb are assigned depending on the size of shortening, supportability and other anatomical and functional features of the stump.

Principles of choosing prosthetic designs and orthopedic products in children with an anomaly in the development of the lower limb

\begin{tabular}{|c|c|}
\hline Problems & Solutions \\
\hline $\begin{array}{l}\text { Shortening of the mal-formed limb as compared with the } \\
\text { intact one }\end{array}$ & $\begin{array}{l}\text { Choice of artificial foot (knee) models bases on the amount } \\
\text { of limb length discrepancy }\end{array}$ \\
\hline $\begin{array}{l}\text { Deformity and deviation from the shape of segments, } \\
\text { joints, reduction in the volume and amplitude of } \\
\text { movements in large joints of an underdeveloped limb in } \\
\text { relation to the intact }\end{array}$ & $\begin{array}{l}\text { The choice of the type of shape of the receiving socket } \\
\text { and materials (thermoplastics, injection resins) for its } \\
\text { manufacture }\end{array}$ \\
\hline $\begin{array}{l}\text { Functional failure of large joints of an underdeveloped } \\
\text { limb (knee, hip) }\end{array}$ & $\begin{array}{l}\text { Modeling of the main load on the sciatic tuberosity in an } \\
\text { atypical hip prosthesis }\end{array}$ \\
\hline $\begin{array}{l}\text { Reduction in the axial supportability of the } \\
\text { underdeveloped limb }\end{array}$ & $\begin{array}{l}\text { Load transfer to the ischial tuberosity by modeling a plate } \\
\text { under it (as in femur prosthesis) }\end{array}$ \\
\hline $\begin{array}{l}\text { Insufficient experience in using prosthetic and } \\
\text { orthopedic products, rehabilitation technical equipment, } \\
\text { various devices by a child }\end{array}$ & $\begin{array}{l}\text { Indication of product designs according to the principle } \\
\text { "from simple to complex" taking into account compensatory- } \\
\text { adaptive mechanisms ("game" locomotion, etc.) }\end{array}$ \\
\hline Low level of psychomotor developn & $\begin{array}{l}\text { Indication of simplified and lightweight OPPs that are } \\
\text { resistant to repeated treatment with disinfectants }\end{array}$ \\
\hline
\end{tabular}


Orthopedic shoes were indicated and manufactured with compensation for shortening with the foot in the shoes in the equinus position and insole layer while sole elevation was increased in cases of shortening of up to $8 \mathrm{~cm}$, preserved axial supportability and good functional condition of the hip and knee joints. They enabled alignment of the position of the pelvis and a decrease in the asymmetry of gait to reduce the risk of overloading on the intact limb and prevent secondary deformations of the spine.

The following requirements were observed in prosthetic management of children with congenital underdevelopment of the lower extremities:

- possibility to expand the prosthesis for not less than $3 \mathrm{~cm}$ for ongoing growth of the child;

- possibility to adjust angular parameters of the prosthesis in the frontal and sagittal planes within $\pm 7^{\circ}$;

- mobility with hinges within the parameters that are biomechanically justified;

- manufacturing of sockets and fasteners, allowing for individual adjustment and frequent hygienic cleaning, ensuring the safe use of the product.

When choosing a prosthesis design for a child with an abnormality in the development of the lower limb, his body weight and the following individual anatomical and functional characteristics were considered:

- supportability of an underdeveloped limb;

- functionality, range of motion, instability of the hip, knee and ankle joints of an underdeveloped limb;

- magnitude of shortening of the underdeveloped limb in comparison with the contralateral one;

- deformities of segments of an underdeveloped limb, deviations of its axis from the axes of the joints;

- symmetry of the joints of an underdeveloped limb relative to the joints of the contralateral limb.

For example, if the clinical and radiological data after the examination of the knee joint of an underdeveloped limb confirmed its ability to actively manage the prosthesis, then a design of the "lower leg prosthesis" was prescribed. If knee and hip joints were inactive, regardless of the size of the shortening, a "femur prosthesis" design was prescribed with a load on the ischial tuberosity (as in femur prosthesis). In such cases, the socket of the product covers the entire underdeveloped limb, regardless of the shortening magnitude, and the product is made as atypical femur prosthesis. Thus, the erroneous indication of orthopedic shoes to compensate for the difference in length with a healthy limb is eliminated.

Prosthetic enterprises (when prostheses are indicated according to functional criteria) have the following designs of modular lower limb prostheses manufactured by RSC Energia: PND3E-1 for a tibial stump, PND3E-2 for a long tibial stump, PND6E-1 for a femur stump 1, PND6E-2 for a long femur stump, and PND8E-1after hip joint disarticulation or hemipelvectomy.

In prosthetic management of children with congenital anomalies of limb development, the experience of the Central Research Institute for Prosthetics and Instrumentation, and in particular, the principles they developed for indication of atypical prostheses, was also taken into account. The results of the analysis of this experience we systematized in Table 5 .

The information presented in Table 5 reflects the functional features of prostheses for children with abnormalities in the development of the lower limb according to the criterion of the knee joint functionality of an underdeveloped limb for active management of the prosthesis. At the same time, this principle of functional classification of prostheses prescribed for malformations of the lower extremity in children replaces the indication of orthopedic devices with a "double trace". The positive quality of the prostheses of a modular design, compared with orthopedic devices, is the presence of a variety of modular components - modules of the feet, artificial knee for various levels of motor activity of the patient.

Prescription of modular prostheses, the details of which are presented in Table 5 , allows a customized manufacture and configuration of a high quality product resulting in a favorable prosthetic fitting. However, at the same time, it is advisable to introduce a shin or thigh prosthesis into the IPRH, rather than an orthosis (orthopedic apparatus) or orthopedic shoes, which should be taken into account by medical specialists of the medical and social expertise.

Table 5

Designs of prostheses for lower limb anomalies in children based on the segment shortening magnitude

\begin{tabular}{|l|l|}
\hline \multicolumn{1}{|c|}{ Lower limb prosthesis designs } & \multicolumn{1}{c|}{ Femur prosthesis designs } \\
\hline $\begin{array}{l}\text { PN9-14D with a combined socket for the thigh and lower } \\
\text { leg of an underdeveloped limb with its attachment on the } \\
\text { sciatic tuberosity, side bars with hinges at the level of the } \\
\text { knee and a foot socket }\end{array}$ & $\begin{array}{l}\text { PN9-10D is used for the total length of the } \\
\text { underdeveloped limb at the level of the femur of the } \\
\text { contralateral (intact) limb }\end{array}$ \\
\hline $\begin{array}{l}\text { PN9-15D with side bars with hinges at the knee level is used } \\
\text { for the total length of the underdeveloped limb at the level of } \\
\text { the middle third of the contralateral lower leg (intact) }\end{array}$ & $\begin{array}{l}\text { PN 9-11D is used for the total length of the } \\
\text { underdeveloped limb at the level of the middle third of } \\
\text { the tibia of the contralateral (intact) limb }\end{array}$ \\
\hline $\begin{array}{l}\text { PN 9-16D with side bars with hinges at the knee level is } \\
\text { used for the total length of the underdeveloped limb at the } \\
\text { level of the lower third of the contralateral lower leg (intact) }\end{array}$ & $\begin{array}{l}\text { PN 9-12D is used for the total length of the } \\
\text { underdeveloped limb at the level of the lower third of the } \\
\text { contralateral lower leg (intact) }\end{array}$ \\
\hline $\begin{array}{l}\text { PN 9-17D with side bars with hinges at the knee level is } \\
\text { used for the total length of the underdeveloped limb at the } \\
\text { level of the total lower leg of the contralateral (intact) limb }\end{array}$ & $\begin{array}{l}\text { PN 9-13B is used for the total length of the } \\
\text { underdeveloped limb at the level of the total lower leg of } \\
\text { the contralateral (intact) limb }\end{array}$ \\
\hline
\end{tabular}


Following the regulatory requirements to the preparation of the basic TMR list, full names of the products should be introduced in the IPRH, for example: "medical training prosthesis of the lower leg (code 8-07-02 or 8-07-06 - for congenital malformation, non-modular)".

In difficult cases of prosthetic fitting, objective results were monitored using a set of instrumental methods based on measuring systems. The reason is the particularly high significance of such control during prosthetic management of children due to inability of the child to independently assess the quality of the prosthesis, clearly formulate complaints and wishes, a higher risk of negative consequences as a result of prosthetic errors. In particular, high adaptive abilities and plasticity of the child's body may mask the consequences of an irrational prosthesis design.

To assess the distribution of pressure over the stump when using the prosthesis, software and hardware complexes with matrix film sensors placed between the stump and the prosthesis socket were used. We determined how consistent is the nature of load distribution along the stump area to medical indications, taking into account its supportability. Focal overload of the stump zones was revealed in order to make the right decision on the advisability of adjusting the shape of the prosthesis socket or using lining elements or rotational modules [13].

In addition, with the help of a high-speed thermal camera, infrared thermography of the skin of the truncated limb was performed after walking on the prosthesis and indirect signs of circulatory disorders in the tissues of the stump were revealed by thermograms. Such signs are hyperthermia of the skin (it can be caused by excessive focal stress on the stump or its friction on the inner surface of the socket, as well as pressure in the area of the neurovascular bundle); distal hyper- or hypothermia after walking and removing the prosthesis (not to be confused with a physiological decrease in temperature in the distal direction of the lower limb), indicating a high risk of venous stasis, in particular due to compression of the stump along the adjustment ring or due to silicone lining without considering contraindications to its use.

These two examination methods complement each other well in assessing the effect of the prosthesis on the stump. Figures 1 and 2 show examples of the results of such examinations performed on the same patient. According to the pressure distribution data on the F-Scan complex (with membrane film sensors), focal overload of stump tissues was revealed, which, when walking slowly, is observed in the lateral condyle, and migrates to the tibial tuberosity region by increased walking speed (Fig. 1). According to the thermal examination with the TVS300-med thermal camera, it is in this area (tibial tuberosity) that local hyperthermia of the stump skin was observed. In addition, distal hypothermia of the truncated limb and local hypothermia in the area of the butt end of the stump, especially pronounced in the zone of the protruding bone end were revealed (Fig. 2). Such results indicate the need for a more thorough examination of the prosthesis socket to solve the question of the feasibility and how to correct it by changing the shape of the socket, finalizing its internal surface, installing additional lining elements.

To identify overloads and prevent deformation of the preserved foot, we analyzed the pressure distribution over its plantar surface in walking. For this purpose, the DiaSled complex (DiaSled-M) was used with matrix pressure sensors (insoles) which were inserted into the patient's shoes during the examination.

Figure 3 presents, as an example, a baroplantogram reflecting the overload on the head of the first metatarsal bone of the preserved foot.

Overload of the forefoot or lateral edge of the preserved foot was a walking peculiarity on the prosthesis characteristic of the examined patients due to lifting on the toe or shifting to the lateral side to compensate for the increase in the functional length of the prosthetic limb, brought over the support of the limb in the prosthesis.

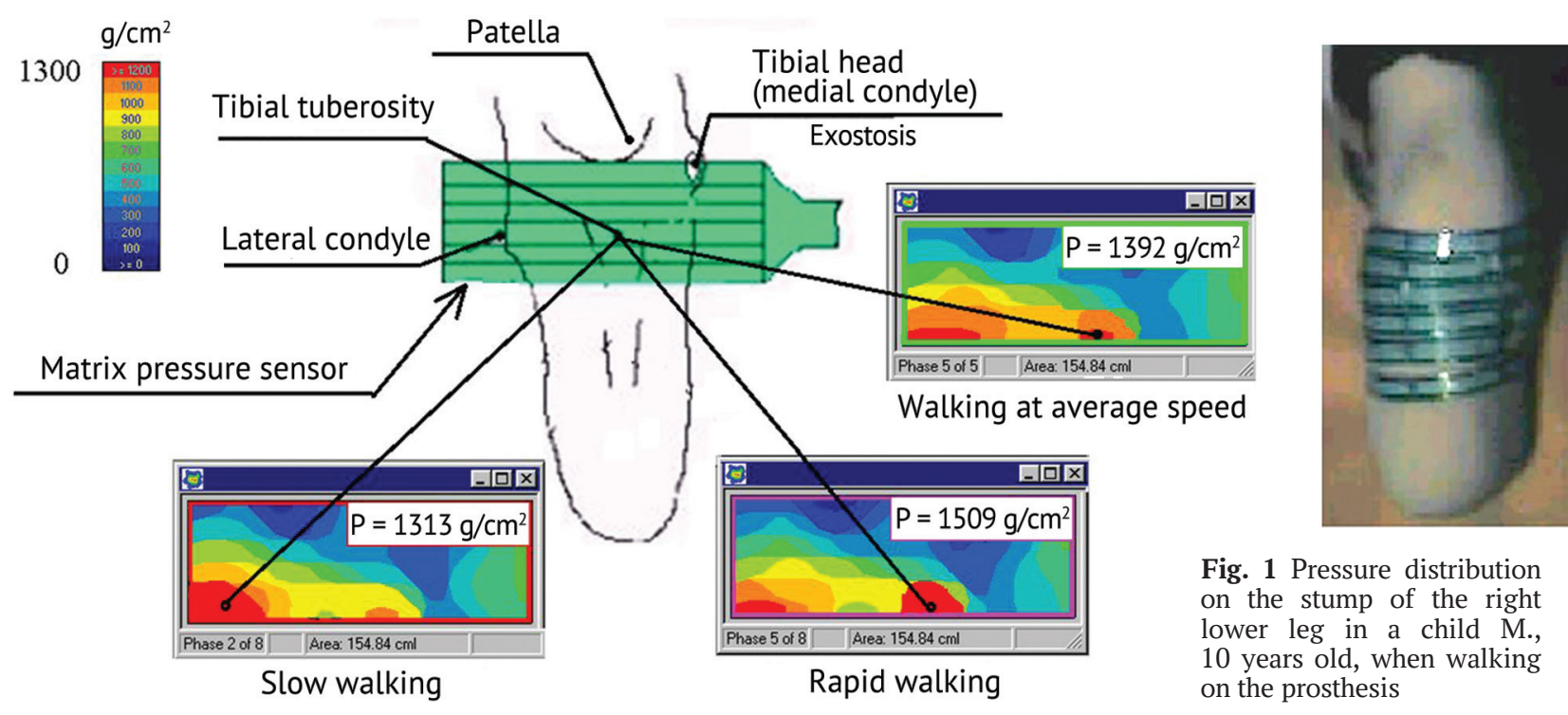




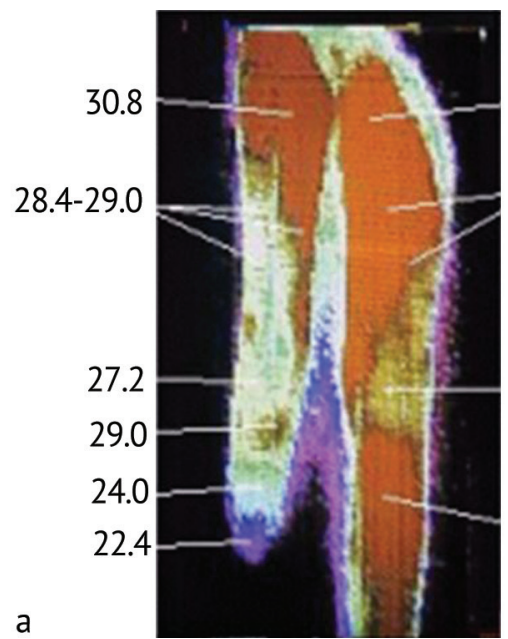

32.0

30.8-31.4
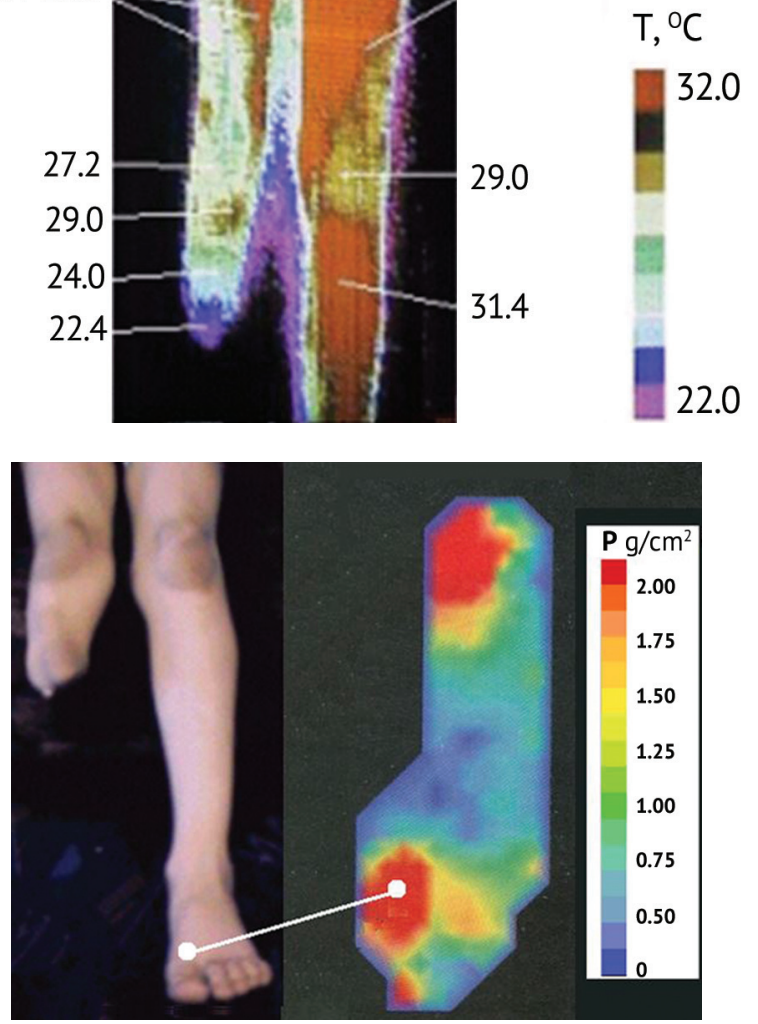

Fig. 3 Baroplantogram of an intact foot in a child M., 10 years old, when walking on the prosthesis of the right lower leg

The work experience of the Federal Research Centre for Rehabilitation of the Disabled has allowed to formulate modern principles of prosthetic management in children with orthopedic pathology of the lower limb:

- administration of a prosthesis at the time of the first attempts of the child to rise on his feet and walk (i.e. from the age of 10-12 months);

- application of simplified and lightweight prosthesis designs that may be easily taken off for frequent hygienic procedures;

- ensuring the safety of the prosthesis, excluding removable small parts or ensuring their reliable fixation to prevent accidental swallowing by the child,
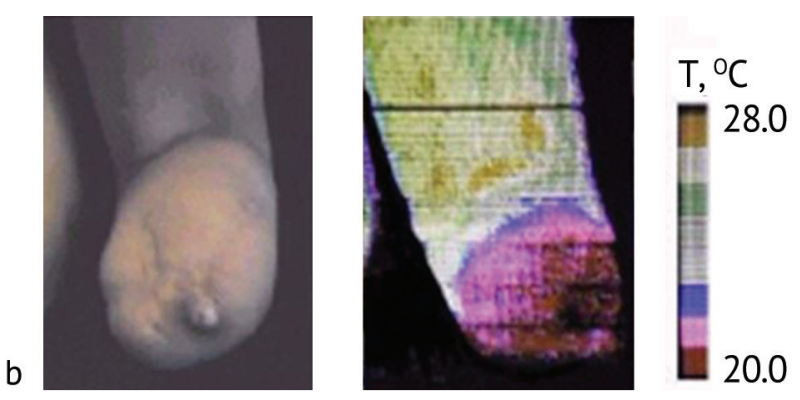

Fig. 2 Thermogram with signs of circulatory disorders in the stump of the right lower leg in a child M., 10 years old, after walking on the prosthesis: $\boldsymbol{a}$ - anterior surface of the lower extremities; $\boldsymbol{b}$ - posterior surface of the stump

penetration into the upper respiratory tract, and injuring the organs of vision and hearing;

- use of elements in the configuration of modular designs of prostheses, allowing the extension of the product as necessary in the process of child's growth;

- indication of modules taking into account the level of motor activity, the anthropometric parameters of the child (including his body weight), the anatomical and functional features of the truncated limb;

- use of additional fasteners for reliable fixation of the prosthesis on the child's body, not restricting or impairing movements, not ressing internal organs, chest, limb (for example, bras, bandages, etc.), allowing multiple hygienic procedures;

- compulsory education of the child in the use of prosthetic and orthopedic products in a hospital under the supervision of specialists, preferably with the use of games (training with game elements), including programmed simulators equipped with a biological feedback system (BFB);

- timely replacement of prosthesis components and adjustment of the sockets as the child grows;

- implementation of the adjustment of the prosthesis individually for each child in order to prevent the development of diseases, defects and deformities of the stump, as well as secondary deformations of the pelvis, spine, intact limb.

The number of prostheses fabricated at the Federal Centre (outpatient and inpatient) for children with lower limb defects, depending on their age and the level of amputation defect, is presented in Table 6.

Table 6

Information on the number of lower limb prostheses fabricated for children at the Federal Centre depending on the age and level of amputation defect

\begin{tabular}{|c|l|c|c|c|}
\hline Age (years) & \multicolumn{1}{|c|}{ Defect level } & 2017 & 2018 & Total \\
\hline \multirow{3}{*}{$3-7$} & Lower leg & 10 & 8 & 18 \\
\cline { 2 - 5 } & Femur & 15 & 7 & 22 \\
\cline { 2 - 5 } & Femur disarticulation & 3 & 0 & 3 \\
\hline \multirow{3}{*}{$7-10$} & Lower leg & 15 & 1 & 16 \\
\cline { 2 - 5 } & Femur & 5 & 4 & 9 \\
\cline { 2 - 5 } & Femur disarticulation & 0 & 0 & 0 \\
\hline \multirow{3}{*}{$10-14$} & Lower leg & 2 & 5 & 5 \\
\cline { 2 - 5 } & Femur & 2 & 0 & 5 \\
\cline { 2 - 5 } & Femur disarticulation & 52 & 28 & 80 \\
\hline
\end{tabular}


Compliance with the requirements for prosthetic fitting in children with congenital mal-formations of the lower extremities and the principles of its implementation set forth in the article enabled to obtain good rehabilitation results in these patients according to instrumental studies and the evaluation of the medical and technical board.

The examination of children that were referred to the Federal Centre for repeated prosthetic fitting focused on asymmetry of the lengths between the affected and intact limb and on the prosthesis socket correspondence to the stump size due to the ongoing growth of children. These problems are inevitable but they should be timely managed.
However, there are cases of delay in prosthetic re-fitting and children had to use the prosthesis for a long time.

Untimely primary or repeated prosthetic fitting in children with orthopedic pathology of the lower extremities significantly increases the risk of possible complications, decreases their motor activity, impairs the development of a growing organism and lead to psychological trauma. For these reasons, during rehabilitation and habilitation of children with orthopedic pathology of the lower extremities in the clinic of the Federal Centre, special attention was paid to the provision of prosthetic care at an earlier term, before the disability was established.

\section{DISCUSSION}

The uneven admission of children with amputation defects of the lower extremity revealed at the clinic of the Federal State Budgetary G.A. Albrecht Scientific Centre of the Ministry of Labour of Russia (Table 1) as a result of the study may be explained, first of all, by the lack of clear regulatory mechanisms for registering patients' data for prosthetic management. A delay in prosthetic management can lead to significant negative impact on the child's body, forced hypodynamia and a decrease in the intensity of the main metabolism (by 15-25\% when compared with healthy children of the same age group). Therefore, attention should be paid, as early as possible, to the need to provide prosthetic management in order to increase the kinematic capabilities of the child and his/her physical activity, contributing to the normal formation of the physiological functions of the body.

The fact that the need for surgical treatment turned out to be higher for defects at the femur level compared to the lower leg and foot (Table 2) may be explained by the complexity of preparation and prosthetic fitting at high amputation levels in rehabilitation organizations located in the regions where patients receive treatment prior to referral to the Federal Centre.

The results obtained, indicating that the main causes of lower limb defects in children admitted for treatment and prosthetic fitting at the Federal Centre were congenital limb malformations do not contradict the known data but specify them $[14,15]$.

In children, in comparison with adult disabled persons, defects of the amputation stump which are more frequent and more pronounced (Table 3) are associated with a resorptive process in the area of the stump end as growth continues due to the functioning of the growth zones, an imbalance in the growth of bones and soft tissues. It is known that growth processes dominate in children up to one year of age; from one year to three years of age the developmental processes dominate, and from three to seven years of age the growth process of the child's body again prevails. Amputation of a limb violates these relationships.

A conical shape of the femur stump which is especially frequent and occurs even in the early stages after amputation is explained by the fact that the femur grows mainly due to the distal growth zone, and the tibia due to the proximal. The results obtained indicate the dependence of the stump conic shape not only on the method and time of amputation and the features of wound healing, but also on the age of children. This dependence is due to the peculiarities of stump formation in children at different age periods. So, in the period of the most intensive growth of a child, the distal segment of the stump often grows ahead of a similar segment of a healthy limb, and as a result, a stump in the upper third of the lower limb can turn into a stump in the middle and even lower third.

In children older than 12 years of age, the activity of the growth zones decreases, and the growth of the stump in length slows down significantly. However, due to the ongoing resorptive processes of the bone, the stump still acquires a conical shape. After amputation of the lower leg, the growth of the fibula dominates, but due to the less intensive growth of this segment of the stump and the presence of two bones in it, the conical shape of the stump of the lower leg is less pronounced than of the femur stump. Physiotherapeutic treatment, physical exercises, and massage before and after surgical treatment have a positive effect on the anatomical and functional state of the lower limb stump in children.

The solutions presented in Table 4 can be recommended to overcome the problems of choosing the design of a prosthetic and orthopedic product for a mal-formed stump in children with an anomaly in the development of the lower limb.

As a rule, children above the age of 10-12 years old are prescribed lower limb prostheses similar to adult patients. It means taking into account the level of motor activity, which is reflected in the order of the Ministry of Labour of Russia dated 12.28.2017 No. 888 "On approval of the list of indications and contraindications to provide disabled individuals with technical rehabilitation means." But the analysis of the situation with prostheses proves the need for more frequent replacement of prostheses in children with congenital and amputation defects of the lower extremities, as compared with adult patients. At the same time, the provision of technical rehabilitation means (TRM) for adult patients is regulated by the current legislation, and the issues of prosthetic management in children have not been adequately regulated by the law and do not take into account the likelihood of stump malformations and deformations of the truncated limb in a child associated with his/her growth, as well as their higher need for surgical treatment. This negative situation requires a speedy solution through appropriate regulatory norms.

\section{CONCLUSION}

Analysis of accumulated experience at the Albrecht Scientific Centre confirmed the provision of early prosthetic and orthopedic care to children with orthopedic pathology of the lower limb as a necessary condition for normalizing the development of their growing body and achieving proper rehabilitation and habilitation. 
The results of rehabilitation and habilitation in children with orthopedic pathology of the lower extremities at the Federal Albrecht Scientific Centre show the need for an objective instrumental assessment of the quality of prosthetic and orthotic management for children, their dispensary observation, monitoring of motor loads and the technical condition of prostheses due to impossible objective and critical assessment of the condition and quality of the prosthesis by children, as well as high risk of secondary deformations and diseases of the locomotor system in childhood.
A special role is responsibility of adults who care after children in training to use prostheses and other TMR and their operation.

Early prosthetic and orthopedic assistance in identifying orthopedic pathology in children should be carried out not only according to the rules of registration of IPRA, but also before disability has been established in order to prevent complications resulting from injuries, diseases of the musculoskeletal system or predicted worsening of functional disorders.

Source of funding Funded by the Albrecht Scientific Centre of the ministry of labour of Russia

Conflict of interests The authors declare that there is no conflict of interests

Ethical statement: the research was conducted in accordance with the ethical standards set forth in the Helsinki Declaration. Informed consent was obtained from all the studied.

\section{REFERENCES}

1. Starobina E.M., Vladimirova O.N., Ishutina I.S., Lorer V.V., Shoshmin A.V., Ermolaeva E.E., Samarina L.V., Kazmin A.M., Mukhamedrakhimov R.Zh. Organizatsiia predostavleniia uslug rannei pomoshchi detiam i ikh semiam: metod. posobie [Organization of providing early care to children and their families: technique manual]. Ponomarenko G.N., ed. SPb., TsIATsAN, 2019, 72 p. (in Russian)

2. Filatov V.I., ed. Protezirovanie detei s defektami konechnostei [Prosthetics in children with limb defects]. L., Meditsina, Leningrad Otd-nie, 1981, 280 p. (in Russian)

3. Spivak B.G., Martyniuk I.V. Primenenie ortezirovaniia v protsesse kompleksnoi reabilitatsii bolnykh, stradaiushchikh detskim tserebralnym paralichom [Orthotics use in the process of complex rehabilitation of patients with children cerebral palsy]. Vestnik Vserossiiskoi Gildii ProtezistovOrtopedov, 2010, no. 4 (42), pp. 33-36. (in Russian)

4. Kurdybailo S.F., Gerasimova G.V., Pavlova S.P. Lechebnaia fizicheskaia kultura v reabilitatsii detei s defektami konechnostei: ucheb. posobie dlia sistemy poslevuz. prof. Obrazovaniia vrache [Exercise therapy in rehabilitation of children with limb defects: manual for the system of post-graduation professional education of physicians]. SPb., Izd. Dom SPbMAPO, 2007, 307 p. (in Russian)

5. Andrievskaia A.O., Iankovskii V.M. Razrabotka kriteriev dvigatelnoi aktivnosti detei v sviazi s protezirovaniem [Working-out the criteria of motor activity of children in connection with prosthetics]. Vestnik Vserossiiskoi Gildii Protezistov-Ortopedov, 2007, no. 2 (28), pp. 54-57. (in Russian)

6. Kurdybailo S.F., Gerasimova G.V. Metodicheskie aspekty vrachebnogo kontrolia za detmi-invalidami s porazheniem oporno-dvigatelnoi sistemy [Methodological aspects of medical controlling disabled children with the locomotor system involvement]. Vestnik Vserossiiskoi Gildii ProtezistovOrtopedov, 2008, no. 2 (32), pp. 39-49. (in Russian)

7. Zuevskii S.E., Spivak B.G., Iakovleva L.N. Protezirovanie detei pri anomaliiakh razvitiia nizhnikh konechnostei [Prosthetics in children for developmental anomalies of the lower limbs]. Protezirovanie i Protezostroenie: sb. tr. M., TsNIIPP (Tsentr. Nauch.-Issled. In-t Protezirovaniia i Protezostroeniia), 1997, vyp. 94, pp. 20-25. (in Russian)

8. Kotelnikov G.P., Chernov A.P. Spravochnik po ortopedii [Manual in Orthopaedics]. M., Meditsina, 2005, 374 p. (in Russian)

9. Mitish V.A., Medinskii P.V., Nalbandian R.T. Spetsializirovannaia khirurgicheskaia pomoshch detiam s oslozhnennym techeniem vysokikh amputatsii v usloviiakh chrezvychainykh situatsii [Specialized surgical care for children with complicated course of high amputations in emergency situations]. Sb. tr. Mezhdunar. Nauch. Prakt. Konf. "Vysokie Amputatsii Nizhnikh Konechnostei u Detei i Vzroslykh", $20-21$ Mai, 2019 [Proc. Intern. Scientific Practical Conference "High Amputations of the Lower Limbs in Children and Adults”, May 20-21, 2019]. M., Izd-vo «Pero», 2019, pp. 90-93. (in Russian)

10. Susliaev V.G., Shcherbina K.K., Smirnova L.M., Sokurov A.V., Ermolenko T.V. Meditsinskaia tekhnologiia rannego vosstanovleniia sposobnosti k samostoiatelnomu peredvizheniiu posle amputatsii nizhnei konechnosti [Medical technology of early recovery of the ability to move independently after the lower limb amputation]. Vestnik Rossiiskoi Voenno-meditsinskoi Akademii, 2019, no. 2 (66), pp. 101-109. (in Russian)

11. Baumgartner R., Botta P. Amputation and prosthetic repair of lower extremities. Stuttgart, 1995, pp. 462-472. (Russ. ed.: Baumgartner R., Botta P. Amputatsiia i protezirovanie nizhnikh konechnostei. Moscow, Meditsina, 2002, 486 p.)

12. Shoshmin A.V., Ponomarenko G.N. MKF v reabilitatsii: (teoriia, struktura, praktika) [IFC in rehabilitation (theory, structure, practice)]. Razumov A.N., ed. SPb., R-KOPI, 2018, 238 p. (in Russian)

13. Susliaev V.G., Iankovskii V.M., Smirnova L.M., Sokurov A.V., Ermolenko T.V. Obosnovanie naznacheniia amortizatsionnykh modulei v protezakh nizhnikh konechnostei [The rationale for the use of damping modules in prostheses of the lower limbs]. Vestnik Meditsinskogo Instituta «Reaviz»: reabilitatsiia, vrach i zdorove, 2018, no. 3, pp. 40-48. (in Russian)

14. Spivak B.G. Klinicheskie proiavleniia anomalii razvitiia s vyrazhennym ukorocheniem nizhnei konechnosti i meditsinskie pokazaniia k primeneniiu sredstv protezirovaniia i ortezirovaniia v protsesse kompleksnoi reabilitatsii detei [Clinical manifestations of the developmental anomalies with marked shortening of the lower limb and medical indications for using prosthetics and orthotics means during complex rehabilitation of children]. Mediko-sotsialnye Problemy Invalidnosti, 2019, no. 2, pp. 42-51. (in Russian)

15. Khobotov S. Osobennosti amputatsii nizhnikh konechnostei i protezirovaniia u detei [Peculiar properties of the lower limb amputation and prosthetics in children]. Ortopediia, Travmatologiia i Protezirovanie, 2013, no. 2, pp. 88-90. (in Russian)

Received: 28.08.2019

\section{Information about the authors:}

1. Vadim G. Susliaev, M.D., Ph.D., Federal Scientific Center of Rehabilitation of the Disabled named after G.A. Albrecht, Saint Petersburg, Russian Federation, The main bureau of medical and social expertise in St. Petersburg, Saint Petersburg, Russian Federation

2. Konstantin K. Shcherbina, M.D., Ph.D., Federal Scientific Center of Rehabilitation of the Disabled named after G.A. Albrecht, Saint Petersburg, Russian Federation, Email: shcherbina180@mail.ru, http://orcid.org/0000-0001-7579-0113

3. Ludmila M. Smirnova, Ph.D. of Engineering Sciences, Professor, Federal Scientific Center of Rehabilitation of the Disabled named after G.A. Albrecht, Saint Petersburg, Russian Federation, Saint Petersburg State Electrotechnical University LETI, Saint Petersburg, Russian Federation,

Email: info@diaserv.ru, http://orcid.org/0000-0003-4373-9342
4. Yury I. Zamilatsky, Ph.D. of Engineering Sciences, Federal Scientific Center of Rehabilitation of the Disabled named after G.A. Albrecht, Saint Petersburg, Russian Federation, Email: info@diaserv.ru, http://orcid.org/0000-0003-4373-9342

5. Andrey A. Koltsov, M.D., Ph.D., Federal Scientific Center of Rehabilitation of the Disabled named after G.A. Albrecht, Saint Petersburg, Russian Federation

6. Andrei V. Sokurov, M.D., Ph.D.,

Federal Scientific Center of Rehabilitation of the Disabled named after G.A. Albrecht, Saint Petersburg, Russian Federation, Email: ansokurov@yandex.ru, http://orcid.org/0000-0002-3736-2895

7. Tatiana V. Ermolenko, M.D., Ph.D.,

Federal Scientific Center of Rehabilitation of the Disabled named after G.A. Albrecht, Saint Petersburg, Russian Federation, Email: tatvalerm@yandex.ru, http://orcid.org/0000-0002-3903-5417 